\title{
PARADIGMA BARU PENGABDIAN KEPADA MASYARAKAT YANG BERKELANJUTAN
}

\author{
Padil $^{1}$, Titi Antin ${ }^{2}$ \\ 1) JurusanTeknik Kimia, FakultasTeknik, Universitas Riau \\ 2) Ketua Forum Layanan Ipteks bagi Masyarakat (FLipMAS) Batobo \\ 3) Jurusan Ilmu Komunikasi, Fakultas Dakwah dan Komunikasi, UIN Suska Riau \\ Surel: fadilpps@yahoo.com
}

\begin{abstract}
This article aims to describe a new paradigm of sustainable community service. The background is the phenomenon is that there is no mutualism symbiosis of various parties and the key actors of empowerment in fulfilling the needs, challenges, and implementation of the community, either directly or indirectly. The method used in this article is literature studies and from various experiences of the author in doing community service. To run and understand the new paradigm of community service, there are at least three models that can be used, namely triple helix, quadruple helix, and quintuple helix. The dynamics of community empowerment require innovations that support sustainable development. The quintuple helix model is relevant for viewing current and future conditions.
\end{abstract}

Keywords: new paradigm, community service, sustainable development, triple helix, quadruple helix, and quintuple helix

\begin{abstract}
ABSTRAK
Penulisan artikel ini bertujuan untuk memaparkan paradigma baru pengabdian kepada masyarakat yang berkelanjutan. Adapun yang menjadi latar belakang penulisan ini karena fenomena yang terjadi belum menunjukkan terjalinnya simbiosis mutualisme dari berbagai pihak dan aktor-aktor kunci pemberdayaan dalam memenuhi kebutuhan, tantangan, dan persoalan masyarakat baik secara langsung maupun tidak langsung. Metode yang digunakan dalam penulisan artikel ini adalah melakukan studi literatur dan dari berbagai pengalaman penulis dalam melakukan pengabdian kepada masyarakat. Untuk menjalankan dan memahami paradigma baru pengabdian kepada masyarakat, minimal ada tiga model yang dapat digunakan yaitu triple helix, quadruple helix, dan quintuple helix. Dinamika pemberdayaan masyarakat membutuhkan inovasi baru yang mendukung pembangunan berkelanjutan. Model quintuple helix menjadi relevan untuk melihat realitas kondisi saat ini dan masa yang akan datang.
\end{abstract}

Kata kunci : paradigm baru, pengabdian kepada masyarakat, pembangunan berkelanjutan, triple helix, quadruple helix, dan quintuple helix 


\section{PENDAHULUAN}

Pengabdian kepada masyarakat menurut Undang-Undang Republik Indonesia Nomor 12 Tahun 2012 tentang Pendidikan Tinggi pasal 1 ayat 11 adalah kegiatan sivitas akademika yang memanfaatkan ilmu pengetahuan dan teknologi untuk memajukan kesejahteraan masyarakat dan mencerdaskan kehidupan bangsa. Pemanfaatan ilmu pengetahuan dan teknologi diperlukan suatu inovasi dalam rangka penciptaan daya saing dan pertumbuhan ekonomi (Praswati A.N., 2017), yang mana inovasi memerlukan interaksi dari berbagai pihak, interaksi ini dikenal dengan konsep helix. Masing-masing pihak memiliki kontribusi yang berbeda sesuai fungsi kelembagaannya. Pihak-pihak yang terlibat dalam menumbuhkan inovasi tersebut diantaranya adalah perguruan tinggi, industri, pemerintah, masyarakat sipil, dan lingkungan alam.

Fenomena yang terjadi selama ini belum menunjukkan terjalinnya simbiosis mutualisme antara berbagai pihak dan aktor-aktor kunci pemberdayaan dalam memenuhi kebutuhan, tantangan, dan persoalan masyarakat baik secara langsung maupun tidak langsung.

Perguruan tinggi merupakan tempat sumberdaya manusia dari berbagai disiplin ilmu yang dapat melahirkan inovasi dalam penerapan sains dan teknologi. Pemerintah memfasilitasi perguruan tinggi melakukan inovasi melalui riset dan penerapannya melalui pengabdian, sedangkan industri memberikan dukungan kepada perguruan tinggi baik dalam kegiatan penelitian dan pengembangan maupun penggunaan hasil riset secara berkesinambungan.

Perguruan tinggi baik negeri maupun swasta yang memiliki lembaga-lembaga riset, cenderung masih menghasilkan informasi dasar dalam berbagai bidang kajian dan lebih mengarah kepada pengembangan kelembagaan perguruan tinggi. Dengan perkataan lain, output riset lebih banyak digunakan dalam rangka pemenuhan angka kredit untuk kenaikan pangkat dan akreditasi program studi dan institusi. Dalam tataran yang demikian, perguruan tinggi memiliki posisi tawar yang lemah dalam konsep helix, dan akibatnya perguruan tinggi belum dapat dipercayai oleh industri dan pemerintah sebagai pembawa inovasi pembangunan berbasis ilmu pengetahuan. Disamping itu pihak-pihak yang terlibat dalam penerapan konsep triple helix belum secara utuh melibatkan masyarakat sipil sebagai pengguna hasil inovasi sains dan teknologi, sehingga sering terjadi apa yang dilakukan oleh perguruan tinggi, industri maupun pemerintah tidak dimanfaatkan oleh masyarakat.

Penerapan sains dan teknologi dalam memunculkan inovasi tidak terlepas dari lingkungan alami masyarakat, sehingga dalam penerapan inovasi harus tetap memperhatikan lingkungan agar pembangunan yang dilakukan tidak hanya berorientasi pada aspek ekonomi semata. Aspek lingkungan menjadi penting diperhatikan demi menjaga masyarakat yang berkelanjutan yaitu untuk menjaga keberlanjutan kehidupan generasi yang akan datang.

Paradigma awal pembangunan hanya menekankan kepada pertumbuhan ekonomi dengan mengabaikan keanekaragaman sosial budaya serta mengakibatkan berbagai kerusakan sumberdaya alam dan lingkungan yang pada gilirannya berdampak pada penurunan kesejahteraan hidup manusia antara lain kemiskinan, penggangguran, penurunan pendapatan, munculnya berbagai macam penyakit yang mengganggu kesehatan manusia, gangguan produksi pangan dan kesenjangan ekonomi.

Carayannis dan Campbell (2009) dan Carayannis et al. (2012) menyatakan bahwa interaksi antara perguruan tinggi, industri, pemerintah, masyarakat sipil, dan lingkungan alam untuk memunculkan inovasi secara cerdas, efektif, dan efisien sangat dibutuhkan untuk menentukan pembangunan berkelanjutan. 
Model inovasi yang menggabungkan pengetahuan dan sistem lingkungan alami bersama-sama ke dalam kerangka 'interdisipliner' dan 'transdisipliner', dapat memberikan model langkah demi langkah untuk memahami manajemen berbasis kualitas pembangunan yang efektif, memulihkan keseimbangan dengan alam, dan membiarkan generasi masa depan memiliki kehidupan pluralitas dan keragaman di bumi (Carayannis dan Campbell 2010; Barth 2011).

Pada tulisan ini akan dikaji tentang perkembangan interaksi antara berbagai pihak. Pemahaman konsep ini dapat memperkuat upaya untuk meningkatkan inovasi yang berujung pada pertumbuhan ekonomi dan daya saing suatu negara.

\section{KAJIAN PUSTAKA}

\section{Triple Helix}

Pada tahun 1995 Henry Etzkowitz dan Loet Leydesdorff memperkenalkan konsep triple helix dalam menganalisa tiga pihak yang saling bersinergi yaitu perguruan tinggi, industri, dan pemerintah. Dimana konsep ini mengadopsi konsep biologi dari model DNA yang berpusat pada hubungan berbagai pihak atau aktor kunci dalam mengembangkan suatu produk berbasis ilmu pengetahuan, ekspansi industri, serta jasa sebagai pondasi dari sistem inovasi.

Gibbons et al. (1994) dalam The New Production of Knowledge dan Nowotny et al. (2001) dalam Re-Thinking Science mengembangkan konsep triple helix dalam rangka menjelaskan hubungan kerja perguruan tinggi, industri, dan pemerintah. Model triple helix ini juga memberikan gambaran mengenai koordinat simbiosis dari berbagai pihak, dimana masingmasing pihak merupakan elemen yang berdiri sendiri dan memiliki peran masing-masing, tetapi ketiga pihak tersebut saling bersinergi dan mendukung dalam menjawab berbagai tantangan yang terdapat pada masyarakat.

Berkembangnya model triple helix di negara-negara maju sebenarnya didasarkan pada beberapa faktor diantaranya adalah perguruan tinggi sebagai gudang ilmu pengetahuan dan teknologi memiliki sumberdaya manusia yang mampu melahirkan inovasi diberbagai bidang yang dapat diterapkan dalam dunia industri, pemerintah yang bersinergi dengan perguruan tinggi melalui bantuan dana riset, dan fasilitas lainnya untuk menghasilkan karya bermutu, dan mengatur perlindungan dan penggunaan hak cipta, serta industri memberikan dukungan kepada perguruan tinggi baik dalam kegiatan penelitian dan pengembangan maupun penggunaan hasil riset secara berkesinambungan (Carayannis and Campbell (2006).

Perguruan tinggi sebagai sumber ilmu pengetahuan dan teknologi, maka perguruan tinggi bukanlah menara gading di tengah arus pembangunan, tetapi harus mampu mengembangkan diri sebagai bagian integral dari proses pembangunan itu sendiri. Sebagaimana dinyatakan Etzkowitz (2010) dalam karya ilmiahnya The Triple Helix Model of Innovation and Action: "university is not only critical to the commercial transformation of knowledge, but also to create space for knowledge, assembling and innovation". Oleh sebab itu, perguruan tinggi harus membenahi dirinya sehingga mampu melakukan pengembangan kapasitas ilmu dan teknologi dan dapat menciptakan strategi pembangunan yang dipandu perguruan tinggi.

Tahun 1995 Etzkowitz dan Leydesdorff mengembangkan model triple helix dengan mengadopsi model inovasi spiral yang mana hubungan timbal balik antara berbagai pihak pada tahap yang berbeda dalam kapitalisasi pengetahuan (Viale dan Ghiglione, 1998). Pendekatan baru interaksi dari berbagai pihak ditandai dengan peran kunci perguruan tinggi 
sebagai produsen pengetahuan utama, peran strategis industri dalam menghasilkan inovasi melalui peningkatan kualitas dan kuantitas produk serta layanan yang ada di pasaran, dan peran yang tidak kalah pentingnya adalah peran pemerintah dalam mendukung pengembangan teknologi berbasis sains dan dalam merumuskan kebijakan yang ditargetkan inovasi (Arnkil et al. 2010).

Perguruan tinggi telah banyak melakukan kerjasama dengan berbagai lembaga, tetapi hasil-hasil riset lebih kepada pemenuhan dokumen-dokumen ilmiah, oleh sebab itu hasil-hasil riset perguruan tinggi belum bisa dimanfaatkan untuk mendorong industri kreatif, dan idustri lebih banyak mengggunakan output riset luar negeri. Tentu kita merasa miris, bila sumberdaya di Indonesia melimpah, tetapi teknologi, modal dan tenaga kerja terdidiknya berasal dari luar Indonesia.

Interaksi dari berbagai pihak dalam model triple helix melalui pendekatan top down, yang mana model ini menekankan pada pertumbuhan ekonomi tanpa memperhatikan sosial dan budaya masyarakat sipil sebagai objek inovasi. Dengan perjalanan waktu model triple helix mengalami perkembangan, dimana masyarakat sipil sebagai pengguna inovasi hasil teknologi dan sains melakukan penyeleksian terhadap inovasi yang berorientasi pada pengguna.

\section{Quadruple Helix}

Dengan perjalanan waktu ternyata masih banyak perdebatan apakah triple helix model (jaringan iptek antara perguruan tinggi, industri, dan pemerintah) telah menjadi sebuah model ideal untuk sistem inovasi di negara miskin dan berkembang. Hal ini menjadi wajar, sebab negara berkembang memiliki warna yang khas, yakni bagaimana sistem inovasi dapat melahirkan teknologi, inovasi ataupun pengetahuan sebagai solusi pengentasan kemiskinan. Dalam tataran ini triple helix model dianggap belum sempurna karena kurang memiliki satu elemen, yakni pelibatan aktif masyarakat sipil. Lebih jauh model ini juga mengisyaratkan masyarakat sipil lebih sebagai objek dari hasil inovasi. Padahal, masyarakat juga memiliki potensi sebagai subjek atau penghasil atau pemberi ide/pengetahuan/teknologi dalam sebuah sistem inovasi. Oleh karena itu, belakangan ini beberapa ekonom mulai memperkenalkan model sistem inovasi baru yang mengena untuk masyarakat sipil, yang disebut dengan quadruple helix model.

Secara paralel, konsep quadruple helix dikembangkan dengan mempertahankan interaksi dari triple helix model (jaringan iptek antara perguruan tinggi, industri, dan pemerintah) serta melibatkan masyarakat sipil secara utuh dalam sistem (Yawson, 2009). Perguruan tinggi dan industri menyediakan kondisi yang diperlukan untuk ekosistem inovasi terpadu. Pemerintah menyediakan kerangka peraturan dan dukungan finansial untuk definisi dan implementasi strategi dan kebijakan inovasi. Masyarakat sipil tidak hanya menggunakan dan menerapkan pengetahuan dan menuntut inovasi dalam bentuk barang dan jasa, namun juga menjadi bagian aktif dari sistem inovasi. Teknologi informasi dan komunikasi (TIK) bekerja sebagai faktor pendukung partisipasi bottom-up masyarakat sipil.

Masyarakat sipil sebagai pengguna hasil inovasi dilibatkan secara utuh dalam model quadruple helix, yang mana inovasi teknologi dan produk disediakan oleh perguruan tinggi dan industri yang berorientasi pada pemenuhan kebutuhan pengguna (masyarakat sipil), karena disadari atau tidak secara de facto masyarakat sipillah yang mengetahui sosioekonomi wilayah tersebut. Proses ini mengisyaratkan bahwa interaksi yang efektif antara perguruan tinggi dan industri serta pemerintah mendukung dari sisi pendanaan dan formulasi kebijakan, ini menunjukkan adanya pergeseran paradigm dari inovasi teknis ke inovasi sosial (Yawson, 
2009). Interaksi dan peranan dari berbagai pihak dalam quadruple helix model dapat dilihat pada Gambar 1.

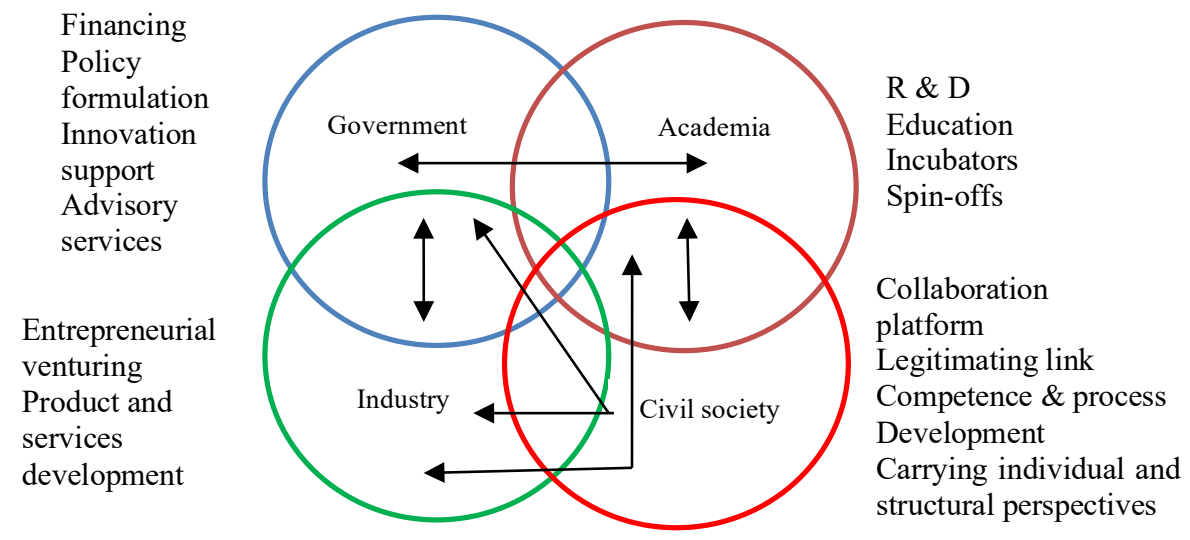

\section{Gambar 1. Interaksi berbagai pihak dalam quadruple helix model dan peranannya}

Arnkil et al. (2010) mengusulkan beberapa jenis quadruple helix model, yang mana masingmasing model yang diusulkan dicirikan oleh inovasi yang spesifik dari siapa inovasi yang dimunculkan dan keterlibatan masyarakat sipil. Model yang pertama yaitu inovasi berasal dari kombinasi industri dan perguruan tinggi sebagai pengusul inovasi, dimana inovasi yang dirancang berdasarkan pada kebutuhan masyarakat sipil. Model yang kedua adalah model lab hidup, dimana inovasi berpusat pada industri dan warga sipil sebagai informan dan pengembang. Model ketiga adalah inovasi berpusat kepada pemerintah, inovasi dirancang dengan warga sipil dengan sistem informasi umpan balik dari warga sipil yang dapat dikumpulkan melalui survey dan wawancara. Model keempat adalah inovasi berpusat pada masyarakat sipil dengan dukungan dari tiga pihak yang lain yaitu industri, perguruan tinggi, dan pemerintah.

Penekanan quadruple helix model adalah pertumbuhan ekonomi dengan inovasi dalam penerapan sains dan teknologi memperhatikan kebutuhan warga sipil, tetapi inovasi yang dilakukan sering sekali menyebabkan terjadinya kerusakan lingkungan, oleh sebab itu para ahli mengembangkan model yang lain yaitu quintuple helix model yang memperhatikan lingkungan.

\section{Quintuple Helix}

Inovasi quintuple helix model yang diajukan oleh Carayannis et al. (2012), mengemukakan bahwa selain perguruan tinggi, industri, pemerintah dan masyarakat sipil, juga memperhatikan lingkungan alam sebagai penentu untuk pembangunan yang berkelanjutan. Menurut Carayannis dan Campbell (2010) quintuple helix selanjutnya menguraikan apa arti pembangunan berkelanjutan.

Quintuple helix model menekankan transisi sosioekologis yang diperlukan masyarakat sipil dan pertumbuhan ekonomi di masa yang akan datang. Oleh karena itu, quintuple helix model sangat mempedulikan ekologis. Dalam kerangka model inovasi quintuple helix, lingkungan alami masyarakat sipil dan pertumbuhan ekonomi dimasa yang akan datang juga harus dilihat sebagai pendorong untuk produksi pengetahuan dan inovasi, sehingga menentukan peluang bagi ekonomi pengetahuan. 
Penerapan inovasi sains dan teknologi melalui quintuple helix model dapat mengatasi tantangan pemanasan global dan kerusakan lingkungan, karena dalam quintuple helix model selain memperhatikan pertumbuhan ekonomi masyarakat sipil juga memperhatikan lingkungan untuk menumbuhkan pembangunan yang berkelanjutan. Oleh sebab itu dalam quintuple helix model dipadukan paradigma yang dapat mengintegrasikan berbagai pihak yang terlibat yaitu perguruan tinggi, industri, pemerintah, masyarakat sipil, dan lingkungan (Barth 2011 ; Permana, 2016).

Quintuple helix model yang menggabungkan penerapan sains dan teknologi dengan sistem lingkungan alami dapat memberikan model langkah demi langkah untuk memahami manajemen berbasis kualitas pembangunan yang efektif, memulihkan keseimbangan dengan alam, dan membiarkan generasi masa depan memiliki kehidupan pluralitas dan keragaman di bumi (Carayannis dan Campbell 2010; Barth 2011). Dari beberapa model yang ada quintuple helix model mewakili model yang sesuai dalam teori dan praktik yang ditawarkan kepada masyarakat sipil untuk memahami kaitan antara pengetahuan dan inovasi, untuk mempromosikan pembangunan yang langgeng.

\section{METODE}

Metode yang digunakan dalam penulisan artikel ini adalah melakukan studi literatur dan dari berbagai pengalaman penulis dalam melakukan pengabdian kepada masyarakat.

\section{HASIL DAN PEMBAHASAN}

Berdasarkan Undang-Undang Republik Indonesia Nomor 12 Tahun 2012 tentang Pendidikan Tinggi pasal 1 ayat 11 , bahwa pengabdian kepada masyarakat adalah inovasi dalam pemanfaatan sains dan teknologi untuk memajukan kesejahteraan masyarakat dan mencerdaskan kehidupan bangsa. Pemanfaatan sains dan teknologi dalam mensejahterahkan masyarakat tentunya tidak terlepas dari memanfaatkan sumber daya alam yang ada. Paradigma pembangunan di negara berkembang maupun dinegara maju terus mengalami perkembangan dan perubahan dari periode satu ke periode yang lain. Periode pertama inovasi pemanfaatan sains dan teknologi lebih menekankan kepada pencapaian pertumbuhan ekonomi untuk meningkatkan kesejahteraan hidup masyarakat sipil yang dimotori oleh perguruan tinggi, industri, dan pemerintah.

Kelemahan dari paradigma pembangunan dengan menggunakan model pertumbuhan ekonomi yang diadopsi oleh banyak negara adalah mengabaikan keanekaragaman sosial dan budaya dari berbagai daerah. Dengan kata lain, paradigma pembangunan berusaha menyeragamkan sistem sosial dan budaya lokal yang berlaku pada berbagai daerah. Padahal setiap daerah memiliki keanekaragaman sosial, kebiasaan dan budaya (Permana, 2016). Paradigma dengan indikator pertumbuhan ekonomi dikenal dengan triple helix model. Inovasi dengan menggunakan triple helix model melakukan pendekatan dengan konsep top down, dengan kata lain program itu dibuat oleh pihak-pihak yang terlibat, tanpa memperhatikan apakah hal tersebut dibutuhkan masyarakat atau tidak. Banyaknya program yang kurang menyentuh terhadap kebutuhan masyarakat sipil menimbulkan pemikiran dari para ahli bahwa pembangunan tidak boleh mengejar pertumbuhan ekonomi saja, melainkan harus memerhatikan sosial, kebiasaan dan budaya masyarakat tempatan, agar program yang di sampaikan benar-benar bermanfaat bagi masyarakat tempatan.

Inovasi yang memerhatikan aspek sosial, budaya dan kebutuhan dari masyarakat tempatan dengan dukungan perguruan tinggi, pemerintah, dan industri disebut dengan quadruple helix model, dimana inovasi dapat dilakukan oleh kerjasama perguruan tinggi dan 
industri dengan tetap menyerap aspirasi dan kebutuhan masyarakat sipil. Dengan kata lain quadruple helix model bersifat bottom up. Sehingga apa yang dilakukan oleh perguruan tinggi, industri, dan pemerintah benar-benar berdasarkan sosial, budaya, dan kebutuhan masyarakat sipil. Dengan perjalanan waktu ternyata triple helix model dan quadruple helix model telah mengakibatkan berbagai kerusakan sumberdaya alam dan lingkungan yang pada gilirannya dapat menurunkan kesejahteraan hidup manusia serta munculnya berbagai macam penyakit yang mengganggu kesehatan manusia (Permana, 2016).

Selama kurun waktu empat dasawarsa terakhir para ilmuwan telah mencatat berbagai kerusakan lingkungan antara lain perubahan iklim, peningkatan pencemaran dan lain-lain yang diakibatkan oleh aktivitas manusia yang hanya mementingkan pertumbuhan ekonomi. Berbagai kerusakan tersebut memunculkan pemikiran para ahli bahwa pentingnya memperhatikan lingkungan alam untuk memenuhi kebutuhan sekarang tanpa mengorbankan generasi yang akan datang untuk memenuhi kebutuhannya. Pemerintah sebagai pengambil kebijakan mestinya memberikan pembatasan terhadap inovasi penerapan sains dan teknologi serta praktek-praktek berlebihan manusia dalam menggelola sumberdaya alam. Dengan kata lain, sumberdaya alam atau lingkungan tidak boleh rusak hanya untuk mengejar pertumbuhan ekonomi semata, tanpa memikirkan generasi yang akan datang. Interaksi antara berbagai pihak dalam penerapan inovasi sains dan teknologi untuk pembangunan berkelanjutan melibatkan perguruan tinggi, industri, pemerintah, masyarakat sipil dengan memperhatikan lingkungan alam sekitarannya. Interaksi pihak-pihak ini disbut dengan quintuple helix model.

Oleh karena itu, dalam sebuah quintuple helix model pertumbuhan ekonomi masyarakat sipil meningkat dengan tetap memperhatikan lingkungan alam sekitarannya, sehingga generasi yang akan datang masih dapat menikmati potensi-potensi sumberdaya alam Indonesia.

\section{KESIMPULAN}

Pengabdian kepada masyarakat yang dilakukan seharusnya memberikan dampak yang positif kepada masyarakat pengguna dan hasilnya bersifat kontinyu dan memperhatikan lingkungan alam sekitar. Quintuple helix model merupakan model yang sangat baik dengan memperhatikan pertumbuhan ekonomi masyarakat dan lingkungan sekitar, sehingga penerapan inovasi sains dan teknologi juga dapat dirasakan oleh generasi yang akan datang.

\section{DAFTAR PUSTAKA}

Arnkil R., Järvensivu A., Koski P. and Piirainen T. ,2010, Exploring Quadruple Helix Outlining user-oriented innovation models, Final Report on Quadruple Helix Research for the CLIQ project, under the Interreg IVC Programme.

Barth, T.D., 2011. The idea of a green new deal in a Quintuple Helix Model of knowledge, know-how and innovation. International Journal of Social Ecology and Sustainable Development, 1(2), 1-14.

Carayannis E. G. and Campbell D. F. J.,2006, Mode 3: meaning and implications from a knowledge systems perspective, in Knowledge Creation, Diffusion, and Use in Innovation Networks and Knowledge Clusters, (pp. 1-25), Westport, CN: Praeger. 
Carayannis E. G. and Campbell D. F. J., 2009, Mode 3 and 'Quadruple Helix': toward a 21st century fractal innovation ecosystem, International Journal of Technology Management, 46 (3), 201-234.

Carayannis E. G. and Campbell D. F. J. 2010, Triple Helix, Quadruple Helix and Quintuple Helix and how do knowledge, innovation and the environment relate to each other? A proposed framework for a transdisciplinary analysis of sustainable development and social ecology, International Journal of Social Ecology and Sustainable Development 2010, 1(1):41-69.

Carayannis E. G., Barth T. D. and Campbell D. F. J. 2012, The Quintuple Helix innovation model: global warming as a challenge and driver for innovation, Journal of Innovation and Entrepreneurship 2012, 1:2.

Etzkowitz H. and Leydesdorff L., 1995, The Triple Helix. University-Industry-Government Relations: A Laboratory for Knowledge-Based Economic Development, EASST Review 14, 14-19. (Viale dan Ghiglione, 1998)

Etzkowitz H. and Ranga M.,2010, A Triple Helix System for Knowledge-based Regional Development: From Spheres to Spaces. (Arnkil et al. 2010)

Gibbons M., Limoges C., Nowotny H., Schwartzman S., Seot P. and Trow M. 1994, The new production of knowledge - The Dynamics of Science and Research in Contemporary Societies, SAGE Publications London.

Nowotny, H, Scott, P, \& Gibbons, M, 2003. Mode 2 revisited: the new production of knowledge. Minerva, 41, 179-194.

Praswati A.N., 2017, Perkembangan model helix dalam peningkatan inovasi, hal 690-705, Prosiding Seminar Nasional Riset Manajemen \& Bisnis, 2017

Permana S., 2016, Antropologi Perdesaan dan Pembangunan Berkelanjutan, Penerbit Deepublish, edisi 1, Yogyakarta, 207

Undang-Undang Republik Indonesia Nomor 12 Tahun 2012 Tentang Pendidikan Tinggi.

Yawson R. M., 2009, The Ecological System of Innovation: A New Architectural Framework for a Functional Evidence-Based Platform for Science and Innovation Policy, The Future of Innovation Proceedings of the XXIV ISPIM 2009 Conference, Vienna, Austria, June 21-24, 2009. 